\author{
J. Stuglik ${ }^{1}$, I.P. Kurytnik ${ }^{1}$, O.M. Vasilevskyi², V.Yu. Kucheruk ${ }^{2 *}$, P.I. Kulakov ${ }^{2}$, \\ S.S. Kassymov ${ }^{3}$, A.K. Khassenov ${ }^{3}$, D.Zh. Karabekova ${ }^{3}$ \\ ${ }^{I}$ The W. Pilecki State Higher School in Oswiecim, Auschwitz, Poland; \\ ${ }^{2}$ Vinnytsya National Technical University, Vinnytsya, Ukraine; \\ ${ }^{3}$ Karagandy University of the name of academician E.A. Buketov, Kazakhstan \\ (*E-mail: vladimir.kucheruk@gmail.com)
}

\title{
Normalization of reproducibility and suitability indexes for assessment of products or production services quality
}

\begin{abstract}
A technique is proposed for estimating the probability of the possible appearance of defective products (or the inconsistency of the production service) on the basis of the suitability and reproducibility indexes of the production process. The index of reproduction is recommended to be calculated on the basis of the standard deviation, which can be established by the average span of the control map and the limits of the tolerance field. At the same time, the production process must necessarily be in a state of statistical controllability. The suitability index can not be calculated on the basis of the control card characteristics, but is calculated solely on the basis of the total of the standard deviation, which is calculated on the basis of the Bessel formula and tolerance limits. The production process does not need to be statistically controllable. Conclusions on the suitability or insufficiency of the products (production services) are based on the value of the indexes of reproduction and suitability, which can take values less than or greater than one. On the basis of the obtained values of these indexes, the probability of production appearance or characteristics of the production process, that does not match the established requirements, is established.
\end{abstract}

Keywords: normalization, quality assessment, product quality, quality of manufacturing services, suitability index, reproducibility index, probability of defective product, production process.

\section{Introduction}

In order to ensure the competitiveness of enterprises products, manufacturers should apply a strategy of continuous improvement. For the implementation of a such strategy, product manufacturers or service providers need to constantly evaluate their products [1]. It is advisable to apply the methods recommended by the international standards of the ISO/TR 18532, ISO 13528 and ISO/TR 22514 [2-5]. For the successful implementation of actions to continually improve the quality of products or services, it is necessary to monitor the sources of the production process deviations and their stability.

In the conditions of competition for producers, not only the price of products or services should be important, but also the costs, that consumers will spend when using products (or services). Therefore, the purpose of any manufacturer should be to continuously reduce the deviations of the production process parameters (ensuring the stability of the production process), and not only compliance with established requirements. The strategy of continuous improvement will reduce the costs associated with failures, and will increase the sustainability of enterprise development in a competitive environment. In addition, reducing deviations will reduce control costs or reduce the frequency of selective control. Quantitative evaluation of deviations allows us to make conclusions about the suitability and conformity of the production process to the established requirements. For identification of deviations, the different methods, such as drawing up a flowchart and identifying inputs and outputs of a production process, using a causal diagram, etc. can be used.

\section{Formulation of the problem}

A number of international standards [1-5] recommend a variety of statistical methods that can be used to manage, control and improve the production process in order to analyze data and evaluate product quality indicators. Therefore, there is the actual problem of the development of mathematical models of the point evaluation of the reproducibility indexes and the suitability of the production process to confirm its statistical stability, as well as the establishment of the defective products probability appearance (or the proportion of units that do not match the requirements), which is the purpose of this article. The description of the mathematical models that can be used to evaluate the quality indexes on the basis of reproduction and suitability 
indexes is an actual scientific task, since many manufacturers of products do not understand their differences and consequently incorrectly interpret the obtained results.

In order to achieve the set purpose of the article, it is necessary to develop methods for evaluating the quality indexes of products (services) on the basis of the indexes of reproducibility and suitability of the production process, as well as to formulate the criteria for normalization of reproduction and suitability indexes for decision-making on conformity (sufficient, satisfactory, good) or non-compliance of product quality indicators or production services to the established requirements.

\section{Research results}

Indicator of the reproducibility of a production process is a measure of its own change of the output characteristics of the production process, which is in a state of statistical control, and which enables to assess the ability of the process to maintain the output characteristics of the production process at the level of requirements set for it. This measure characterizes the variability that remains after eliminating all known causes. If the control of the production process is carried out using a control card, then the control card shows that the production process is in a controlled state $[4,6]$. Reproducibility of the production process is often estimated by the number of products, the characteristics of which are within the tolerance field. Since the production process in a statistically controlled state can be described by the predicted distribution law, then the quantity of products which characteristics is beyond the tolerance field can be estimated. While the production process remains in a state of statistical control, the manufactured products have, on average, the same proportion of the defective products (products that do not match the established requirements).

The actions of the production process management, which are aimed to reducing the deviations caused by accidental causes, will make it possible to improve the conformity of the production process with the requirements of the quality management system. To do this, it is necessary: to determine the characteristics of the production process and the conditions of operation (if the conditions are changed, then new studies of the characteristics of the production process are necessary); to evaluate the parameters of short-term and longterm deviations in the form of percentages from full changes and to minimize them; maintain the stability of the production process and ensure its statistical control; to evaluate the own variability of the reproduction process; select the required parameter of the reproducibility of the production process.

Also, it is necessary to check the control card, the data of which had been used for statistical control, and the histogram data with all the established limits applied to it. In addition, it is necessary to check the normality of the distribution law by a valid criteria, for example, such as the Anderson-Darling criteria [7] or the $\chi^{2}$-criteria [4]. These criteria are effective in detecting the deviation of the law of distribution from normality on the distribution tails, since this area is important in the evaluation of the indexes of reproduction and suitability of the production process. Also, an abnormal data explanation must be found and appropriate actions taken with the data to calculate the investigated parameter. Exclusion of data allocated to others is unacceptable. Such deviations can be very informative about the properties of the production process and should be investigated.

Reproducibility parameter of the production process may be a value that characterizes one or more properties of the distribution of the input characteristic in the conditions of the production process reproducibility. The general parameter of the distribution position is the mean (mathematical expectation) $\mu$, but sometimes selective median $\mathrm{X}_{50} \%$ is used. For a normal distribution law, the best position parameter is the median.

The best parameter characterizing the own variability of the production process is the standard deviation $\sigma-$ index of reproducibility of the production process. It is recommended to evaluate it according to the average magnitude $\bar{R}$ obtained by the control card, when the production process is stable and is in a state of statistical control

$$
\hat{\sigma}=\frac{\bar{R}}{d_{2}},
$$

where $d_{2}$ is a constant corresponding to the sample size in the subgroup, its value is chosen from Table 1 [8]. 


\section{Coefficients of the control card to estimate the standard deviation}

\begin{tabular}{|c|c|c|}
\hline Sample size $(n)$ & $d_{2}$ & $c_{4}$ \\
\hline 2 & 1.128 & 0.7979 \\
\hline 3 & 1.693 & 0.8862 \\
\hline 4 & 2.059 & 0.9213 \\
\hline 5 & 2.326 & 0.9400 \\
\hline 6 & 2.534 & 0.9515 \\
\hline 7 & 2.704 & 0.9594 \\
\hline 8 & 2.847 & 0.9650 \\
\hline 9 & 2.970 & 0.9693 \\
\hline 10 & 3.078 & 0.9727 \\
\hline
\end{tabular}

If we use the average standard deviation for controlling deviations within a subgroup, which is determined by the data of the control card, then the own standard deviation of the production process can be estimated by the formula

$$
\hat{\sigma}=\frac{\bar{S}}{c_{4}},
$$

where $S$ - average sampled standard deviation; $c_{4}$ — the constant corresponding to the sample size in the subgroup $(n)$, its value is chosen from Table 1.

If for each subgroup it is possible to calculate the standard deviation of a subgroup, then a formula for assessing the standard deviation of the production process is recommended, which gives a more accurate estimate than formulas (1) and (2), which is described by formula

$$
\hat{\sigma}=\sqrt{\frac{\sum_{j=1}^{m} S_{j}^{2}}{m},}
$$

were $S_{j}$ - sampled standard deviation of $j$-th subgroup; $m$ - is the number of subgroups with $n$ observations in each subgroup.

It is also necessary to distinguish between the standard deviation, that characterizes only short-term changes in the production process, and the standard deviation that characterizes the long-term changes in the production process. And the data received over a long period of time have bigger value of standard deviation due to a more significant change in the production process. In this case, it is recommended to use the symbol $\sigma_{t}$ to denote the standard deviation - the total (full) standard deviation.

If the data are obtained from the observation of a production process that is not in a state of statistical control or if control cards have not been used, then formula (1)-(3) should not be used to calculate the standard deviation, but it is necessary to apply the following formula

$$
\hat{\sigma}_{t}=\sqrt{\frac{\sum_{i=1}^{N}\left(x_{i}-\bar{x}\right)^{2}}{N-1}},
$$

where $N$ - total sample size; $x_{i}$ - the $i$-th value in the sample; $x$ - average arithmetic mean.

Equation (4) should be used when the production process has a change in the average value due to the presence of a systematic error [9], which can not be excluded, and this variability must be taken into account with along the random variability. This variation parameter is also suitable for use in the calculation of the suitability indexes of the production process.

With the normal distribution of the production process as an estimate of the reproducibility of the production process, an expression can be used

$$
\overline{\bar{x}} \pm z_{\alpha} \cdot \hat{\sigma}_{t},
$$

where $\overline{\bar{x}}=\sum_{j=1}^{m} \bar{x}_{j} / m$ - the arithmetic average of several sample meanings; $\bar{x}_{j}$ - selective average of $j$-th subgroup; $z_{\alpha}$ is a quantile of a normalized normal distribution law. 
The choice of the value of $z_{\alpha}$ depends on the used value of the reproducibility index of the production process in units of production of one million. Typically, $z_{\alpha}$ is assigned a value of 3,4 or 5 . If the reproducibility index of the production process matches the requirements, $z_{\alpha}=3$ means an average of 2700 units of products per million beyond the requirements. Similarly, $z_{\alpha}=4$ means an average of 64 units of products per million that do not match the established requirements, and $z_{\alpha}=5$ means an average of 0.6 such items per million.

Reproducibility indexes of the production process are the point of estimation of their reference values. Using the reproducibility index of the production process allows us to characterize the state of the production process. The index of reproducibility of the production process is the ratio between the differences of the tolerance field to the length of reference interval

$$
C_{p}=\frac{U-L}{X_{99.865 \%}-X_{0.135 \%}},
$$

where $L$ - lower limit of the tolerance field; $U$ - the upper limit of the tolerance field; $X_{0.135 \%}$ - the lower limit of the reference interval defined as the quantile of distribution at the level of $0.135 \% ; X_{99.865 \%}$ - the upper limit of the reference interval, which is defined as quantile of distribution at $99,865 \%$.

To estimate the index of reproducibility of the production process the reference interval $T=Y 2-Y 1$ is used $[4,5]$, which includes $99.73 \%$ of the production process characteristics values, which are in the state of statistical control. At the same time $0.135 \%$ of each side of the distribution law is cut off $[4,5]$. This interval is recommended to apply even in the case of a non-normal distribution law of the production process characteristics values $[4,10,11]$. For a normal distribution law, the length of the reference interval is six standard deviations (Fig. 1).

Control maps are usually used to evaluate reproducibility. If the control card shows weakened control lines or modified control lines, the actual standard deviation of the process will be greater than the standard deviation obtained from the control card with standard control lines. These features affect the reference interval, so it is important that the standard control lines were fixed in the evaluation of the reproducibility index of the production process.

A reproducible process is a production process with a reference interval $T$ smaller than the tolerance field $(L, U)$ for a certain value, as shown in Figure 1.

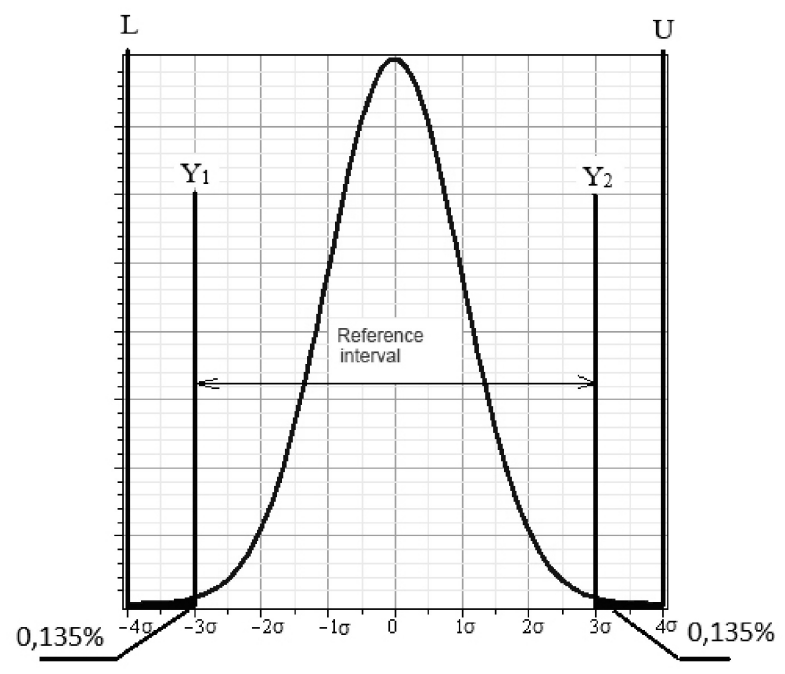

Figure 1. The length of the reference interval $T$ and the lower $L$ and the upper $U$ limits of the tolerance field

It is also recommended by international standards $[1,3,4]$ to use other indexes that characterize both the state and the variability of the production process, for example, the reproducibility index $C_{p k}$. If this index is smaller than a given value, then it can be assumed that in the manufacturing process there is a high probability of occurrence of defective products, that is, the characteristic of the production process goes beyond the tolerance field $(L, U)$. 
The reproducibility indexes $C_{p k}$ can be defined as the ratio of difference between the tolerance field and the production process value to the difference between the corresponding limits of the production process value and the parameter of the production process:

$$
\begin{aligned}
C_{P k U} & =\frac{U-X_{50 \%}}{X_{99.865 \%}-X_{50 \%}}, \\
C_{P k L} & =\frac{X_{50 \%}-L}{X_{50 \%}-X_{0.135 \%}},
\end{aligned}
$$

where $X_{50 \%}$ - the quantile of the distribution law of the production process at the level of $50 \%$.

These reproducibility indexes $\left(C_{P k L}, C_{P k U}\right)$ provide information about how tightly the characteristics are routed around the centerline and whether product specification requirements may be violated. Even if the value of the index $C_{P}$ is high, then the low values of the $C_{P k}$ indexes indicate that the production process is poorly concentrated around the central line, and the probability of the appearance of quality characteristics values beyond the established limits of the set requirements is high.

If the observed values are distributed according to the normal distribution law, the length of the reference interval is equal to $6 \hat{\sigma}$, and the reproducibility index can be estimated by expression

$$
\hat{C}_{p}=\frac{U-L}{6 \hat{\sigma}} \text {. }
$$

If the distribution of individual values is subject to the normal distribution law, then quantile $X_{50 \%}$ is equal to the mathematical expectation $\mu$, and the upper and lower indexes of the reproducibility $C_{P k}$ can be estimated from the expressions:

$$
\begin{gathered}
\hat{C}_{P k U}=\frac{U-\mu}{3 \hat{\sigma}}, \\
\hat{C}_{P k L}=\frac{\mu-L}{3 \hat{\sigma}} .
\end{gathered}
$$

Based on the evaluation of the lower $\hat{C}_{P k L}$ and upper $\hat{C}_{P k U}$ reproducibility indexes, for the final evaluation of the reproducibility index $C_{P k}$, it is necessary to assume a lower reproducibility index

$$
\hat{C}_{P k}=\min \left(\hat{C}_{P k L}, \hat{C}_{P k U}\right) \text {. }
$$

In calculating the reproducibility index of the production process, it must be taken into account that the variability of the production process should correspond to the situation when the data has been obtained in a state of statistical control of the production process.

If the index of the reproducibility $C_{P}<1$ ( or $C_{P k}<1$ ), then the upper $U$ and the lower $L$ limits of the tolerance field are inside the reference interval $T$ of the production process - this means that the production is not possible without a defect, and the production process is unsatisfactory (the probability of defective production is very high and may be higher than $0.27 \%$ ).

If the value $C_{P}=1$ (or $C_{P k}=1$ ), then the upper $U$ and the lower $L$ limits of the tolerance field coincide with the reference interval $T$ of the production process. In this case, if the process is centered and the distribution of quality indicators obeys the normal law, then the possible lack of products is $0.27 \%$ (2700 defective products per 1 million manufactured goods). In this case, the production process is considered to be the minimum acceptable (satisfactory, it is recognized as reproducible).

If the value of the reproducibility index $C_{P}>1$ (or $C_{P k}>1$ ), then the upper $U$ and the lower $L$ limits of the tolerance field are outside the reference interval $T$ of the manufacturing process - this means that production is possible without defects, and the production process is considered to be satisfactory. If the value $C_{P k}$ (or $C_{P}$ ) lies within $1<C_{P k}<1.33$, then the probability of occurrence of defective products will be in the range from $0.006 \%$ to $0.27 \%$. If the value of the index of reproducibility is greater than 1.33 $\left(C_{P k}>1,33\right)$, then the probability of occurrence of defective products is less than $0,006 \%$, and the production process is considered good.

The appropriateness of the production process regarding the quality of products is the achieved distribution of results. The only important difference between the suitability and reproducibility of the production 
process is that for assessing the suitability of the production process there is no requirement for the presence in the production process of the state of statistical control and control cards.

In the analysis of the suitability of the production process:

a) all technical conditions, including requirements for the production environment, such as temperature and humidity requirements et al., must be established [12-15];

b) requirements for uncertainty of measurements must be established $[9,16-20]$;

c) an opportunity should be provided for the analysis of multi-factor and multi-level aspects of the production process;

d) data must be obtained and registered within a specified time period;

e) the frequency of sampling and the start and end of time of the data obtaining must match the requirements set by the quality management system [1];

f) the process may not be monitored by a control card;

g) the process may be statistically uncontrolled, in particular, previously obtained data, which sequence is unknown, can be used to assess the suitability of the production process.

The index of the suitability of the production process is a statistical indicator, which is determined by the output characteristic of the production process, which used to evaluate the production process, the location of which in the state of statistical control is not confirmed. The parameter of the suitability of the production process may be the quantities describing one or more properties of the quality characteristic distribution in terms of suitability. To estimate the suitability parameter, in contrast to the reproducibility parameter, under the normal distribution of the quality characteristic, we can only by expression (4). The index of the suitability of a production process is an index that reflects the stability of the production process to the specified field of tolerance.

If the values of the parameters under study are distributed according to the normal distribution law, then the length of the reference interval is equal to $6 \hat{\sigma}[10,11]$. Therefore, the value of the index of fitness $P_{P}$ can be calculated by expression

$$
P_{p}=\frac{U-L}{6 \hat{\sigma}_{t}} .
$$

The upper $P_{P k U}$ and lower $P_{P k L}$ indexes of the suitability of the production process can be estimated by the expressions:

$$
\begin{gathered}
P_{p k U}=\frac{U-\bar{x}}{3 \hat{\sigma}_{t}}, \\
P_{p k L}=\frac{\bar{x}-L}{3 \hat{\sigma}_{t}} .
\end{gathered}
$$

The indexes of the suitability of the production process $P_{P k}$ is assumed to be equal to the lower of the two values of $P_{p k U}$ and $P_{p k L}$, i.e. $P_{P k}=\min \left(P_{P k U}, P_{P k L}\right)$. The lower the value of the index of suitability, the greater the probability of occurrence of defective products, and the production process will not match the established requirements.

As follows from expressions (13)-(15), the assessment of the indexes of suitability is similar to the evaluation of reproducibility indexes (6)-(12). The difference in the evaluation of suitability indexes from the reproducibility indices is that the production process does not necessarily have to be statistically controlled, and the standard deviation that characterizes the best indicator of the suitability of the production process can not be calculated based on the parameters of the control card.

The $P_{P k}$ suitability index characterizes the confirmed quality. If the production process is centered, that $P_{P k}=P_{P}$, but when the process is shifted, the suitability index is shifted from its nominal value, and $P_{P k}$ becomes less than $P_{P}$. The high $P_{P k}$ index will only be the case when the goal is achieved with a minimum deviation from the average arithmetic value.

In case of noncentration of the production process, the $P_{P}$ index can be adjusted by introducing a noncentral correction

$$
P_{P k}=(1-k) P_{P},
$$


where $k$ - a corrective coefficient that corresponds to the value of noncentration and is defined as the difference between the given reference value of the product characteristic and the average value of the production process parameter.

If the process is centered, then $k=0$ and $P_{P k}=P_{P}$. If the process is shifted relative to a given reference value, then $k$ increases and the index $P_{P k}$ becomes smaller than the $P_{P}$ index.

If the suitability indexes are equal $\left(P_{P k}=P_{P}\right)$, the production process is within the tolerance. If the in$\operatorname{dex} P_{P}<1$, then this means that the production process has low accuracy and the production process is unsatisfactory. The using of statistical methods [3-5] during the regulation will not give the necessary effect. In this case, it is necessary to improve the accuracy of the production process by replacing (or/and repairing) technical equipment and ensuring the quality of measurements (unity of measurements and accuracy of measurements) [21].

If the $P_{P k}$ suitability index is in the range from 1 to $1.33\left(1 \leq P_{P k}<1.33\right)$, the production process has sufficient accuracy - this means that the procedure for setting it up is correct. At the same time it is advisable to apply the acceptance control cards and to combine the procedure of manufacturing process regulation and the acceptance of products in one common procedure of the SPC (Statistical Process Control) [22].

If the index $P_{P}>1.33$, then the production process is considered to be good (with high potential accuracy). If $P_{P}>1$ and $P_{P k}<1$, then the production process is considered to have sufficient potential precision, but there are factors that shift the manufacturing process and remain unnoticed. In this case, it is recommended to use Shuhart's control cards to identify factors that may result in displacement of the manufacturing process center. If the index $P_{P}>1.66$, then the production process is ideally configured [23, 24].

The main properties of the normal distribution law, on which the calculation of the defect fraction is based, are shown in Figure 2.

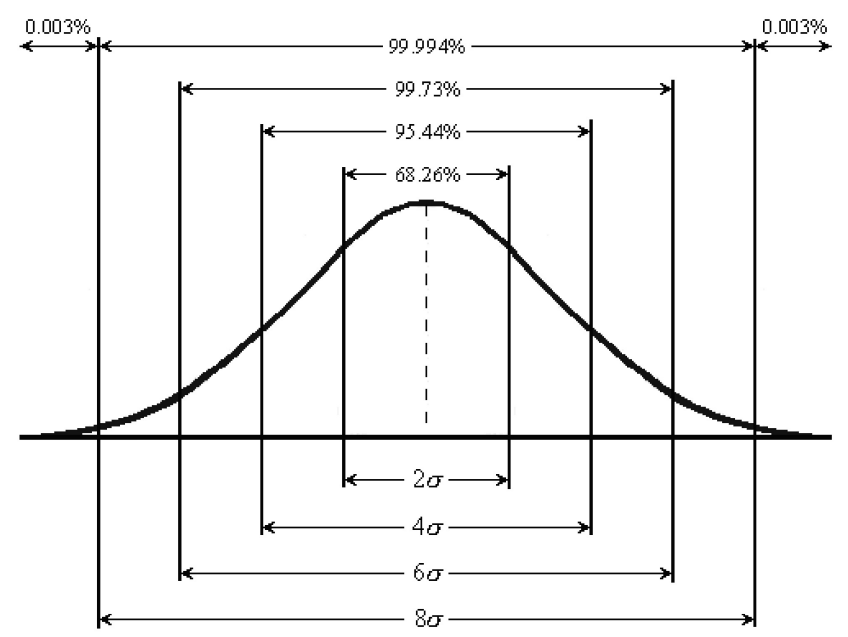

Figure 2. Properties of the normal distribution law, on which the calculation of the defect fraction is based

As it follows from Figure 2, in order to avoid a noticeable fraction of defective products or characteristics of the production process that deviates from the established requirements, the width of the tolerance field must be not less than $6 \sigma$.

Estimation of the values of $\hat{p}_{t}$ production process characteristic or the quality parameter of products that do not match the requirements under the normal distribution law can be found on the basis of the upper and lower parts of units that do not match the requirements:

$$
\begin{aligned}
\hat{p}_{t}=\hat{p}_{L}+\hat{p}_{U} & =\Phi\left(\frac{L-\bar{x}}{\hat{\sigma}_{t}}\right)+\Phi\left(\frac{\bar{x}-U}{\hat{\sigma}_{t}}\right) ; \\
\hat{p}_{L} & =1-\Phi\left(3 \hat{C}_{P k L}\right) ; \\
\hat{p}_{U} & =1-\Phi\left(3 \hat{C}_{P k U}\right),
\end{aligned}
$$


where $\hat{p}_{L}$ - assessment of the lower part of the units that do not match the requirements - the part of units of the process or product characteristics distribution, which does not exceed the lower limit of the field of tolerance $L ; \hat{p}_{U}$ - assessment of the upper part of the units that do not match the requirements - the part of units of the process or product characteristics distribution, that exceeds the upper limit of the tolerance field $U ; \Phi$ - the function of a normalized normal distribution law.

In order to estimate the proportion of product units that do not match the requirements of the suitability of the production process, it is necessary to replace the reproducibility indexes and indexes of suitability in formulas (18) and (19), and thus common part of the values of the characteristics distribution of the production services (production process) that may go beyond the tolerance field.

\section{Conclusions}

The quality of products or services is largely determined by the effectiveness of the quality management system at the enterprise and the proper organization of the production process. The quality management system, built in accordance with the principles of overall quality management, involves continuous improvement of the marketing activities of the enterprise, improving the quality of products and ensuring of the needs of all interested parties, both customers and producers, through the establishment of appropriate management in the enterprise [25-30].

The application of indexes of reproducibility and suitability of the production process in the system of quality control allows us to visually estimate the possibility of reducing the percentage of defective products by reducing and eliminating the effects of non-random causes of the production process parameters deviation (ensuring the stability of the production process), as well as reducing the impact of the random reasons leading to deviations of the production process parameters. This will allow timely warning and corrective actions that will enable them to find reserves for improving product quality, reduce financial costs for defective repair, and increase the competitiveness of the enterprise.

The reproducibility index and suitability index are not related to the mean of the process. That is, when the entire distribution is shifted, the reproducibility index and the fitness index will not change, it will only respond to the variation of the spread or sweep. The reproducibility index and the suitability index will be equal to one when the variation of $6 \sigma$ is equal to the tolerance. If the indices are greater than one, then the range is less than the tolerance, if the indices are less than one, then the variation is greater than the tolerance. It should be taken into account that since the indices are not related to the position of the mean, then when the mean is far beyond the tolerance, the value of the indices may be much greater than one.

The accuracy of the proposed estimation methodology of the reproducibility and suitability index, which includes the proposed mathematical apparatus, was estimated on the basis of the correctness index, the method of assessment of which is carried out in accordance with the international standard ISO 5725-2:2002 [6]. The measure of correctness of the proposed method is the combined uncertainty of type $\mathrm{B}$, the relative value of which does not exceed $0.05 \%$, and the efficiency of the model is determined by the level of the methodological component of probability, which was estimated by the method given in, the value of which is not less than $95 \%$.

\section{References}

1 Quality management systems — Fundamentals and vocabulary: HOST R ISO 9000:2015. [effective from 2015-09-15]. Geneva: ISO copyright office, 2015. — P. 57 (International Standard).

2 Guidance on the application of statistical methods to quality and to industrial standardization: ISO/TR 18532:2009. [effective from 2009-04-15]. — Geneva: ISO copyright office, 2009. - P. 204 (International Standard).

3 Statistical methods in process management - Capability and performance - Part 2: Process capability and performance of time-dependent process models: ISO 22514-2:2017. [effective from 2017-02-06]. — Geneva: ISO copyright office, 2017. — P. 21 (International Standard).

4 Statistical methods in process management - Capability and performance - Part 4: Process capability estimates and performance measures: ISO/TR 22514-4:2016. [effective from 2016-07-04]. Geneva: ISO copyright office, 2016. — P. 45 (International Standard).

5 Statistical methods for use in proficiency testing by interlaboratory comparisons: ISO 13528:2015 [effective from 2015-0801]. Geneva: ISO copyright office, 2016. - P. 89 (International Standard).

6 Accuracy (trueness and precision) of measurement methods and results - Part 2: Basic method for the determination of repeatability and reproducibility of a standard measurement method - Technical Corrigendum 1: ISO 5725-2:2003. [effective from 2003-06-01]. Geneva: ISO copyright office, 2003. — P. 23 (International Standard). 
7 Stephens M. Anderson-Darling Test for Goodness of Fit / M. Stephens // Encyclopedia of Statistical Sciences. — 1982. Vol. 1. - P. 81-85.

8 Control charts - Part 2: Shewhart control charts: ISO 7870-2:2013. [effective from 2013-04-25]. Geneva: ISO copyright office, 2013. - P. 44 (International Standard).

9 Vasilevskyi O. A new approach to assessing the dynamic uncertainty of measuring devices / O. Vasilevskyi, P. Kulakov, D. Kompanets, O.M. Lysenko, V. Prysyazhnyuk, Waldemar Wojcik, D. Baitussupov // Proceedings of SPIE - The International Society for Optical Engineering. — 2018. — P. 257-268. https://doi.org/10.1117/12.2501578.

10 Beckert S. Critical analysis of the acceptance criteria used in measurement systems evaluation / S. Beckert, W. Paim // Int. J. of Metrology and Quality Engineering. - 2017. - Vol. 8(23). - P. 1-9.

11 Vasilevskyi O.M. Vibration diagnostic system for evaluation of state interconnected electrical motors mechanical parameters / O.M. Vasilevskyi, P.I. Kulakov, I.A. Dudatiev, V.M. Didych, A. Kotyra, B. Suleimenov, A. Assembay, A. Kozbekova // Proceedings of SPIE - The International Society for Optical Engineering. - $2017 . \quad-\quad 104456 \mathrm{C}$ - P. 348-358; https://doi.org/10.1117/12.2280993.

12 Meng X. Effect of retro-reflective materials on building indoor temperature conditions and heat flow analysis for walls / X. Meng, T.Luo, Z.Y. Wang, W. Zhang, B. Yan, J.L. Ouyang, E.S. Long // Energy Build. — 2016. — Vol. 127. — P. $488-498$.

13 Szelag-Sikora A. Impact of Integrated and Conventional Plant Production on Selected Soil Parameters in Carrot Production / A. Szelag-Sikora, J. Sikora, M. Niemiec, Z. Gródek-Szostak, J. Kapusta-Duch, M. Kuboń, M. Komorowska, J. Karcz // Sustainability. - 2019. - Vol. 11. - P. 1-13.

14 Kucheruk V. Measurement of the Number Servings of Milk and Control of Water Content in Milk on Stall Milking Machines / V. Kucheruk, P. Kulakov, N. Storozhuk // Advances in Intelligent Systems and Computing. — 2017. — Vol. 543. — P. 435-447. DOI: $10.1007 / 978-3-319-48923-0 \_46$.

15 Kucheruk V. Optical method to determine the quantity of water in milk using the visible radiation range / V. Kucheruk, P. Kulakov, O. Vasilevskyi, D. Mostovyi, A. Kulakova, I.M. Kobylyanska, G. Karnakova, P. Kisala // Proceedings of SPIE — The International Society for Optical Engineering. — 2018, 10808, 108080Y. — P. 123-126.

16 Vasilevskyi O. Calibration method to assess the accuracy of measurement devices using the theory of uncertainty / O. Vasilevskyi // Int. J. of Metrology and Quality Engineering. — 2014. — Vol. 5(4). — P. 403(p1)-403(p9).

17 Kucheruk, V.Yu. Computer-measuring system of the induction motor's dynamical torque-speed characteristics / V.Yu. Kucheruk, I.P. Kurytnik, Ye.Z. Oshanov, P.I. Kulakov, A.A. Semenov, D.Zh. Karabekova, A.K. Khassenov // Bulletin of the university of Karaganda-Physics. — 2019. - № 2(94). - P. 92-100. DOI: 10.31489/2019Ph2/92-100

18 Vasilevskyi O. The method of translation additive and multiplicative error in the instrumental component of the measurement uncertainty / O. Vasilevskyi, V. Kucheruk, V. Bogachuk, K. Gromaszek, W. Wójcik, S. Smailova, N. Askarova // Proceedings of SPIE - The Int. Society for Optical Engineering. - 2016. - P. 125-132.

19 Kucheruk, V. Definition of dynamic characteristics of pointer measuring devices on the basis of automatic indications determination / V. Kucheruk, I.P. Kurytnik, P. Kulakov, R. Lishchuk, Y. Moskvichova, A. Kulakova // Archives of Control Sciences. 2018. - Vol. 28(LXIV), No. 3. - P. 335-352. DOI: 10.24425/acs.2018.124709

20 Vasilevskyi O. Method of evaluating the level of confidence based on metrological risks for determining the coverage factor in the concept of uncertainty / O. Vasilevskyi, V. Didych, A. Kravchenko, M. Yakovlev, I. Andrikevych, D. Kompanets, Y. Danylyuk, W. Wójcik, A. Nurmakhambetov // Proceedings of SPIE — The international society for optical engineering. - 2018. Retrieved from: http://ir.lib.vntu.edu.ua/bitstream/handle/123456789/22915/48076.pdf; jsessionid=4C469153E21B74681C99 B368CB6A8F86? sequence $=2$

21 Accuracy (trueness and precision) of measurement methods and results - Part 2: Basic method for the determination of repeatability and reproducibility of a standard measurement method: ISO 5725:2019. [effective from 2019-12-20]. London: BSI, 2019. - P. 78 (International Standard).

22 Guidelines for implementation of statistical process control (SPC) — Part 1: Elements of SPC: ISO 11462-1:2001. [effective from 2001-06-15]. Geneva: ISO copyright office, 2001. - P. 32 (International Standard).

23 Demchuk L. Combined usage of Theory of Constraints, Lean and Six Sigma in quality assurance of manufacturing processes / L. Demchuk, R. Baitsar // Key Engineering Materials. - 2015. - Vol. 637. - P. 21-26.

24 Demchuk L. Achievement Particularities of Application of Theory of Constraints, Lean and Six Sigma for Ensuring the Quality of Proucts and Processes / L. Demchuk, R. Baitsar // Intern. Journal Sustainable Development. — 2014. — Vol. 16. — P. 98-103.

25 Staniškis J.K. Unsustainability reduction in enterprises by incremental innovations implementation and management / J.K. Staniškisa, E. Katiliūtèb // Journal of Cleaner Production. - 2019. - Vol. $236 . \quad-\quad$ P. 117542. https://doi.org/10.1016/j.jclepro.2019.07.017.

26 Medina Munroe M. Analyzing external environment factors affecting social enterprise development / M. Medina Munroe, C. Belanger // Soc. Enterp. J. — 2017. — Vol. 13. — P. 138-152. 10.1108/SEJ-06-2016-0021

27 Mazzej M. Different ways of dealing with tensions: practices of (re)negotiation in local social economies / M. Mazzej // Soc. Enterp. J. - 2017. - Vol. 13. - P. 299-314.

28 Chan A. Supported social enterprise: a modified social welfare organization / A. Chan, S. Ryan, J. Quarter // Nonprofit and Voluntary Sector Quarterly. — 2016. — Vol. 46(2). — P. 261-279.

29 Hullavarad S. Enterprise content management solutions-roadmap strategy and implementation challenges / S. Hullavarad, R. O'Hare, A.K. Roy // International Journal of Information Management. — 2015. — Vol. 35 (2). — P. 260-265.

30 An L. Modeling human decisions in coupled human and natural systems: review of agent-based models. / L. An // Ecol. Modell. - 2012. - Vol. 229. - P. 25-36. 


\title{
И. Стуглик, И.П. Курытник, О.М. Василевский, В.Ю. Кучерук, П.И. Кулаков, С.С. Касымов, А.К. Хасенов, Д.Ж. Карабекова \\ Өнімнің немесе көрсетілетін қызметтердің сапасын бағалау үшін қайта өндіру және жарамдылық индекстерін қалыпқа келтіру
}

\begin{abstract}
Ақауы бар өнімнің (немесе өндірістік қызметтің сәйкес келмеуінің) өндірістік процестің жарамдылығы мен шығарылу индексі негізінде пайда болу мүмкіндігін бағалау әдістемесі ұсынылған. Репродуктивтілік индексін стандартты ауытқу негізінде есептеу ұсынылады, оны бақылау картасының орташа ауқымы мен төзімділік өрісінің шегі бойынша орнатуға болады. Бұл ретте өндірістік процесс міндетті түрде статистикалық басқарылу жағдайында болуы тиіс. Жарамдылық индексі бақылау картасының сипаттамалары негізінде есептелмейді, тек жалпы стандартты ауытқу негізінде есептеледі, ол Бессель формуласының көмегімен және төзімділік өрісінің шегі негізінде анықталады. Сонымен қатар, өндірістік процесс міндетті түрде статистикалық тұрғыдан басқарылмауы керек. Өнімнің (өндірістік көрсетілетін қызметтердің) жарамдылығы немесе жарамсыздығы туралы тұжырымдар бірліктен аз немесе одан да көп мәндерді қабылдауы мүмкін қайта өндіру және жарамдылық индекстерінің мәні негізінде жүзеге асырылады. Осы индекстердің алынған мәндерінің негізінде белгіленген талаптарға сәйкес келмейтін өнімнің немесе өндірістік процесс сипаттамаларының пайда болуының ықтимал үлесі белгіленеді.
\end{abstract}

Кілт сөздер: қалыпқа келтіру, сапаны бағалау, өнімнің сапасы, өндірістік қызметтердің сапасы, жарамдылық индексі, репродуктивтілік индексі, өнімнің ақаулану ықтималдығы, өндірістік процесс.

\author{
И. Стуглик, И.П. Курытник, О.М. Василевский, В.Ю. Кучерук, \\ П.И. Кулаков, С.С. Касымов, А.К. Хасенов, Д.Ж. Карабекова
}

\section{Нормализация индексов воспроизводимости и пригодности для оценки качества продукции или услуг}

\begin{abstract}
Предложена методика оценки вероятности возможного появления бракованной продукции (или несоответствия производственной услуги) на базе индексов пригодности и воспроизводимости производственного процесса. Индекс воспроизводимости рекомендуется рассчитывать на основе стандартного отклонения, которое может быть установлено по среднему размаху контрольной карты и пределам поля допуска. При этом производственный процесс обязательно должен быть в состоянии статистической управляемости. Индекс годности не может быть определен на основе характеристик контрольной карты, а рассчитывается исключительно из общего стандартного отклонения, которое определяется с помощью формулы Бесселя и пределов поля допуска. При этом производственный процесс не обязательно должен быть статистически управляемым. Выводы о пригодности или непригодности продукции (производственных услуг) осуществляются на основе значения индексов воспроизводимости и пригодности, которые могут принимать значения меньше или больше единицы. На основе полученных значений этих индексов устанавливается возможная доля появления продукции или характеристик производственного процесса, не соответствующих установленным требованиям.
\end{abstract}

Ключевые слова: нормализация, оценка качества, качество продукции, качество производственных услуг, индекс пригодности, индекс воспроизводимости, вероятность брака продукта, производственный процесс.

\section{References}

1 Quality management systems - Fundamentals and vocabulary. Switzerland (2015). HOST R ISO 9000:2015 from 15 ${ }^{\text {th }}$ September 2015. Geneva: ISO copyright office.

2 Guidance on the application of statistical methods to quality and to industrial standardization. Switzerland (2009). ISO/TR 18532:2009 from $15^{\text {th }}$ April 2009. Geneva: ISO copyright office.

3 Statistical methods in process management - Capability and performance - Part 2: Process capability and performance of time-dependent process models. Switzerland (2017). ISO 22514-2:2017 from $6^{\text {th }}$ February 2017. Geneva: ISO copyright office.

4 Statistical methods in process management - Capability and performance — Part 4: Process capability estimates and performance measures (2016). ISO/TR 22514-4:2016 from $4^{\text {th }}$ July 2016. Geneva: ISO copyright office.

5 Statistical methods for use in proficiency testing by interlaboratory comparisons. Switzerland (2016). ISO 13528:2015 from $1^{\text {st }}$ August 2015. Geneva: ISO copyright office.

6 Accuracy (trueness and precision) of measurement methods and results - Part 2: Basic method for the determination of repeatability and reproducibility of a standard measurement method - Technical Corrigendum 1. (2003). ISO 5725-2:2003 from $1^{\text {st }}$ June 2003. Geneva: ISO copyright office, 2003. - P. 23 (International Standard). 
7 Stephens, M. (1982). Anderson-Darling Test for Goodness of Fit. Encyclopedia of Statistical Sciences, 1, 81-85.

8 Control charts - Part 2: Shewhart control charts (2013). ISO 7870-2:2013 from $25^{\text {th }}$ April 2013. Geneva: ISO copyright office.

9 Vasilevskyi, O. Kulakov, P., Kompanets, D., Lysenko, O.M., Prysyazhnyuk, V., \& Waldemar Woicik, et al. (2018). A new approach to assessing the dynamic uncertainty of measuring devices. Proceedings of SPIE — The International Society for Optical Engineering, 257-268. https://doi.org/10.1117/12.2501578.

10 Beckert, S., \& Paim, W. (2017). Critical analysis of the acceptance criteria used in measurement systems evaluation. Int. J. of Metrology and Quality Engineering, 8(23), 1-9.

11 Vasilevskyi, O.M., Kulakov, P.I., Dudatiev, I.A., Didych, V.M., Kotyra, A., \& Suleimenov, B. (2017). Vibration diagnostic system for evaluation of state interconnected electrical motors mechanical parameters. Proceedings of SPIE - The International Society for Optical Engineering, 104456C, 348-358; https://doi.org/10.1117/12.2280993.

12 Meng, X., Luo, T., Wang, Z.Y., Zhang, W., Yan, B., \& Ouyang, J.L., et al. (2016). Effect of retro-reflective materials on building indoor temperature conditions and heat flow analysis for walls. Energy Build, 127, 488-498.

13 Szeląg-Sikora, A., Sikora, J., Niemiec, M., Gródek-Szostak, Z., Kapusta-Duch, J., Kuboń, M., et al. (2019). Impact of Integrated and Conventional Plant Production on Selected Soil Parameters in Carrot Production. Sustainability, 11, 1-13.

14 Kucheruk, V., Kulakov, P., \& Storozhuk, N. (2017). Measurement of the Number Servings of Milk and Control of Water Content in Milk on Stall Milking Machines. Advances in Intelligent Systems and Computing, 2017, 543, 435-447. DOI: 10.1007/978-3-319-48923-0_46.

15 Kucheruk, V., Kulakov, P., Vasilevskyi, O., Mostovyi, D., Kulakova, A., \& Kobylyanska, I.M., et al. (2018). Optical method to determine the quantity of water in milk using the visible radiation range. Proceedings of SPIE - The International Society for Optical Engineering, 10808, 108080Y, 123-126.

16 Vasilevskyi, O. (2014). Calibration method to assess the accuracy of measurement devices using the theory of uncertainty. Int. J. of Metrology and Quality Engineering, 5(4), 403(p1)-403(p9).

17 Kucheruk, V.Yu., Kurytnik, I.P., Oshanov, Ye.Z., Kulakov, P.I., Semenov, A.A., Karabekova, D. Zh., \& Khassenov, A.K. (2019). Computer-measuring system of the induction motor's dynamical torque-speed characteristics. Bulletin of the university of Karaganda-Physics, 2(94), 92-100. DOI: 10.31489/2019Ph2/92-100

18 Vasilevskyi, O., Kucheruk, V., Bogachuk, V., Gromaszek, K., Wójcik, W., Smailova, S., \& Askarova N. (2016). The method of translation additive and multiplicative error in the instrumental component of the measurement uncertainty. Proceedings of SPIE - The Int. Society for Optical Engineering, 125-132.

19 Kucheruk, V., Kurytnik, I.P., Kulakov, P., Lishchuk, R., Moskvichova, Y., \& Kulakova, A. (2018). Definition of dynamic characteristics of pointer measuring devices on the basis of automatic indications determination. Archives of Control Sciences, 28(LXIV), 3, 335-352. DOI: 10.24425/acs.2018.124709

20 Vasilevskyi, O., Didych, V., Kravchenko, A., Yakovlev, M., Andrikevych, I., \& Kompanets, D., et al. (2018). Method of evaluating the level of confidence based on metrological risks for determining the coverage factor in the concept of uncertainty. Proceedings of SPIE - The international society for optical engineering. 2018. Retrieved from: http://ir.lib.vntu.edu.ua/bitstream/ handle/123456789/22915/48076.pdf; jsessionid=4C469153E21B74681C99B368CB6A8F86? sequence=2

21 Accuracy (trueness and precision) of measurement methods and results - Part 2: Basic method for the determination of repeatability and reproducibility of a standard measurement method (2019). ISO 5725:2019 from $20^{\text {th }}$ December 2019. London: BSI.

22 Guidelines for implementation of statistical process control (SPC) - Part 1: Elements of SPC (2001). ISO 11462-1:2001 from $15^{\text {th }}$ June 2001. Geneva: ISO copyright office.

23 Demchuk, L., \& Baitsar, R. (2015). Combined usage of Theory of Constraints, Lean and Six Sigma in quality assurance of manufacturing processes. Key Engineering Materials, 637, P. 21-26.

24 Demchuk, L., \& Baitsar, R. (2014). Achievement Particularities of Application of Theory of Constraints, Lean and Six Sigma for Ensuring the Quality of Proucts and Processes. Intern. Journal Sustainable Development, 16, 98-103.

25 Staniškis, J.K., \& Katiliūtèb, E. (2019). Unsustainability reduction in enterprises by incremental innovations implementation and management. Journal of Cleaner Production, 236, 117542. https://doi.org/10.1016/j.jclepro.2019.07.017.

26 Medina Munroe M., \& Belanger, C. (2017). Analyzing external environment factors affecting social enterprise development. Soc. Enterp. J., 13, 138-152.

27 Mazzej, M. (2017). Different ways of dealing with tensions: practices of (re)negotiation in local social economies. Soc. Enterp. J., 13, 299-314.

28 Chan, A., Ryan, S., \& Quarter, J. (2016). Supported social enterprise: a modified social welfare organization. Nonprofit and Voluntary Sector Quarterly, 46(2), 261-279.

29 Hullavarad, S., O'Hare, R., \& Roy, A.K. (2015). Enterprise content management solutions-roadmap strategy and implementation challenges. International Journal of Information Management, 35(2), 260-265.

30 An, L. (2012). Modeling human decisions in coupled human and natural systems: review of agent-based models. Ecol. Modell, 229, 25-36. 